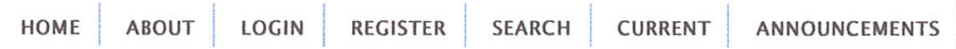

Home $>$ Multi-, inter- and transdisciplinary research in Landscape Archaeology

Landscape archaeology is a rapidly expanding field of research that is covered by scholars from an increasing number of disciplines, such as archaeology, earth sciences, historical geography, ecology and anthropology. In order to stimulate international debate and exchange of research experiences and theoretical ideas between these disciplines, in January 2010 it was decided to start a series conferences at two years intervals.

The 3rd International Landscape Archaeology Conference took place 17th - 20th of September 2014 at the Royal Netherlands Institute in Rome (KNIR) and the Swedish Institute was organized by CLUE+, the research institute for Culture, Cognition, History and Heritage of the VU University Amsterdam'. These proceedings are published under the auspices of CLUE+.

Multi-, inter- and transdisciplinary research in Landscape Archaeology

\section{Table of Contents}

The wind of change: town, country, land-use and settlement patterns between the fourth and the seventh century $\mathrm{AD}$

Prologue: Wind of change from the Ural Mountains to Atlantic Lusitania between the forth and the seventh centuries $A D$

Francesca Carboni

Early medieval settlements and land use in the Kislovodsk basin (North Caucasus) D.S. Korobov

La Cilicia/Isauria tra IV e metà VII secolo: insediamenti, produzioni e attività economiche. Nuove considerazioni alla luce dei più recenti studi sulla regione Veronica lacomi, Valentina Cassiani

An imperial town in a time of transition. Life, environment, and decline of early Byzantine

\section{Caričin Grad}

Jago Jonathan Birk, Ivan Bugarski, Sabine Fiedler, Vujadin Ivanišević, Henriette Kroll,

Nemanja Marković, Anna Reuter, Constanze Röhl, Rainer Schreg, Aleksandar

Stamenković, Sonja Stamenković, Miriam Steinborn

Recapturing the Dynamics of the Early Byzantine Settlements in Crete: Old problems | New Interpretations through an Interdisciplinary Approach

Christina Tsigonaki, Apostolos Sarris

Settlement dynamics and site hierarchies in western Sicily from fourth to seventh C. AD interpretative challenges in the Contessa Entellina Survey Antonino Facella

Estrazione e raffinazione dello zolfo e paesagqio nella Sicilia romana tra IV e VI d.C.

Luca Zambito

Changes and Transformations of the Spatial Structure and Landscape in the Area of L'Aquila between the Fourth and Eighth Centuries $A D$

Fabio Redi

Roman Order and Early Christian Redefinition: Crossed Archeological and Anthropological Analysis from Riva del Garda (TN)

Cristina Bassi, Valeria Amoretti

The Early Christian Sanctuaries and the Transformation of Italian Landscape Alessandro Luciano

The Transformation and Christianisation of Urban Landscapes in Central Lusitania during Late Antiquity and the Early Middle Ages: the Cases of Ammaia and Ebora lulia Emilia Gallo

Epilogue: In Search of an Identity: Landscape Archaeology for Post-Classical Studies.

Defining and Understanding Archaeological Landscapes

Cristina Cors

Archaeomorphology as landscape archaeology: new approaches and perspectives

Archaeomorphology as Landscape Archaeology: New Approaches and Perspectives

Hector A. Orengo, Josep M. Palet
Username

Password

$\square$ Remember me 
The Landscapes of the Ancient Appia Proiect: Formation and Degeneration Processes in

tication of the Benevento Area.

Alessandro Terribile, Cristiano Benedetto De Vita

L'analisi archeomorfologica delle reti viarie come studio delle dinamiche evolutive del

paesagqio. Il caso della bassa pianura veneta tra Padova e Rovigo

PDF

Michele Matteazz

Más allá de la herencia medieval. Una nueva arqueomorfología para el paisaje histórico de Valencia.

Maria Jesús Ortega, Hèctor A. Orengo, Josep M. Palet

The Identification of Land Divisions in the Ancient Mediterranean through Integrated

Remote Sensing and GIS Applications

Jamieson C. Donati

Le SIG comme outil de détection et d'analyse des parcellaires antiques

Maxime Seguin

Paths and settlement in a Roman rural landscape: An archaeomorphological analysis in

the Congost Valley (Barcelona, Spain) / Trazas viarias y poblamiento en un paisaje rural

romano: análisis arqueomorfológico en el valle del río Conqost (Barcelona)

Arnau Garcia, Josep M. Palet, Marta Flórez

Archaeomorphology and Agrimensores: problem or opportunity?

Saskia Roselaar

Archaeology of Commons: a Multidisciplinary Approach to the Reconstruction of Multiple

Uses and Conflicts on European Uplands

Anna Maria Stagno

Archaeomorphological and Geological Studies on the Ancient Appian Way at the Aurunc

Pass: Multidisciplinary Approaches for the Investigation of Ancient Ouarries Siting and

Exploitation.

Paola Carfora, Emiliano Di Luzio

Tumulus Culture Burial Mounds in the Landscape - Krotoszyn Forest Area: the Beginnings

of a New Project.

Mateusz Stróżyk

L'antico sistema delle acque nella Valle della Caffarella

Angela Paolini, Fabrizio Piccari

Ancient topography and archaeology of landscape

Intrasite Artefact Survey at Terravecchia di Cuti (Sicily)

Oscar Belvedere, Aurelio Burgio

Turlough Hill - Place-making and Mountains in Prehistoric Ireland

Stefan Bergh

Contributo alla carta archeologica di Ruvo di Puqlia e del suo territorio Giovina Caldarola

The Archaeological Map for the Reconstruction of the Ancient Topography of the Greek

and Roman City of Taormina

Lorenzo Campagna, Giuseppe Scardozzi

Mura urbiche nell'Italia centro-settentrionale: siqnificato e funzione tra la fine della

repubblica e la prima età imperiale

The Territory of Mesagne ( $\mathrm{Br}$ ) between the Roman Age and Late Antiguity

New Approaches in Landscape Analysis of the Bronze Age in Central-Western Sardinia: the Area of Mogoro (Oristano - Italy)

Ricardo Cicilloni, Giuseppina Ragucci, Marco Cabras, Alberto Mossa

Studi qeofisici per la topografia antica e l'archeologia del paesagqio: l'area archeologica d

Elisa Di Giovanni, Ida Gennarelli, Paolo Mauriello, Natascia Pizzano

Ancient Topography of the Mid Calore Vallev: the City of Aeclanum and its Territory

Immacolata Di Taranto 
Ancient Topography Research in the Territory of Rodi-Milici (Messina): Preliminary Results

Archeologia dei paesagai: il territorio di Licata (AG) e la bassa valle dell'Himera

Gioacchino Francesco La Torre, Alessio Toscano Raffa

La trasformazione storico-topografica delle aree di confine: un esempio dal suburbio ovest di Roma

Mirella Serlorenzi, Giorgia Leoni, Federica Lamonaca

Carta Archeologica D'italia - Forma Italiae Project: Research Method

Maria Luisa Marchi

Archeologia Globale ad Egnazia: nuove acquisizioni dalla città e dal territorio

Gianluca Mastrocinque

Ploughsoil Assemblages and Bevond: Some Interpretative Challenges

andscapes of Southern Apulia: Integration and Interpretation of Gis-Based Data in a Multi-Methodological Research

Alfio Merico, Mariangela Sammarco

Survey in the Inland Area of Lilybaeum Annapaola Mosca

Verucchio and its Hinterland. Landscape Archaeology in the Valmarecchia Alessando Naso, Simon Hye, Christoph Baur

L'intervisibilità. Analisi del paesaqgio nella chora della colonia areca di Himera Maria Assunta Papa

Landscape Archaeology in the Ager Telesinus: Scientific Results and Land-Use Planning Giuseppina Renda

Sistemi di sfruttamento agricolo nell'ager Faliscus: I Prata di C. Egnatius (Corchiano - Vt) Francesca Rizzo

Late Middle Ages in Central/Northern Italy: a Case Study of Emilia-Romagna (Southern

Area) and Marche (Nothern Area)

Daniele Sacco

Un progetto di ricerca tra topografia antica e archeologia dei paesaggi: I'Appia antica ne territorio di Beneventum

Alfonso Santoriello, Amedeo Rossi

Carte archeologiche nella Provincia di Viterbo: tra conoscenza e conservazione

Giuseppe Scardozz

Ancient Topography in Southern Etruria: an Appraisal of Twenty Years of Research

Marcello Spanu

Spectacles and their Relation with the Roman-Period Civic Planning

Paolo Storchi

Upper Agri Vallev (Basilicata) between Ceomorphology and Ancient Settlements

Francesco Tarlano, Julian Bogdani, Antonio Priore

Knowledge and CNR GIS for Cultural Heritage

Computational modeling in landscape archaeology: back to the drawing board?

Examining the Utility of Model Calibration and Verification as a Means of Testing

Archaeological Computational Models

Marieka Brouwer Burg

Simulating the Farm: Computational Modelling of Cattle and Sheep Herd Dynamics for the

Analysis of Past Animal Husbandry Practices

Jamie Joyce, Philip Verhagen

Estimating "Land Use Heritage" to Model Changes in Archaeological Settlement Patterns

Laure Nuninger, Philip Verhagen, Frédérique Bertoncello, Angelo Castrorao Barba 
D.F.A.M. van den Biggelaar, S.J. Kluiving, J. Kolen, C. Kasse

Modelling the Dynamics of Demography in the Dutch Roman Limes Zone

Philip Verhagen, Jamie Joyce, Mark Groenhuizen

Human Energetics and the Modelling of Cultural Landscapes

Seeing heritage through the lenses of landscapes

Introduction: Seeing Heritage through the Lens of Landscape - New Approaches in Landscape Archaeology Based on the Fusion of Heritage and Landscape

Graham Fairclough, Bas Pedroli, Niels Dabaut

Archaeological and Ethnographic Survey in the Paikuli Area (Iraqi Kurdistan)

Connecting the Museum with the Landscape: a Geographical Solution for the Pigorini

Museum, Rome

Arjuna Cecchetti

The Landscape of Ancient Caere through Historic Air Photographs

Patrizia Tartara

Appalachian Landscape and Architecture through the Lens of Extraction

Peter Butler, Charlie Yuill

3D Laser Recording and the "Naturalised" Urban Landscape of Göreme, Kapadokya. Turkey

Soundscape, Landscape and Cultural Heritage: A Case Studv in Proto-Historic Italy Sonia Modica

Citizen Participation and Heritage Management in Rural Landscape Contexts

LAC 2014 proceedings - ISBN 978-90-825296-0-9 - is an open access initiative supported by the University Library, Vrije Universiteit Amsterdam. 


\title{
Ploughsoil Assemblages and Beyond: Some Interpretative Challenges
}

\author{
Simonetta Menchelli \\ Università di Pisa, Dipartimento Civiltà e Forme del Sapere \\ email: simonetta.menchelli@unipi.it
}

\begin{abstract}
The present remarks derive from on-going topographic-archaeological projects focusing on North coastal Etruria and South Picenum. These studies apply a global archaeology approach that includes diachronic and interdisciplinary research. In our projects particular attention is being paid to palaeogeographic aspects. Processual methodology standards are applied to our research; nevertheless, geomorphologic, spatial and quantitative evidence is integrated with qualitative and symbolic data to reconstruct all the anthropic activities. Some remarks will be made about the informative potential of ploughsoil findings, landscape complexity, strategies in collecting and studying pottery and on the importance of considering the absence of particular categories of materials. Following this global approach and its consequential theoretical framework and rigorous methodology, archaeologists will be able to take up the interpretative challenge of defining landscapes in terms of their different components: sites, off-sites and their historical-functional classification. Obviously, the objective and subjective standards used for these classifications have to be explained clearly, so that the research results of a district can be used for comparisons and large-scale analyses.
\end{abstract}

Keywords: Etruria, Picenum, Survey, Off-Sites, Pottery

This paper derive from ongoing topographic-archaeological projects focusing on North coastal Etruria lager Pisanus and Volaterranus; maritime landscapes from Vada Volaterrana to Lunal and
South Picenum lager Firmanus and Asculanus: the upper valleys of the Tenna and Aso rivers) (see the most recent works Menchelli, 2014; Pasquinucci \& Menchelli, 2012b; in press) (figs. 1-2).

These studies apply a global archaeology approach larcheologia globale: Mannoni, 1985; total archaeology: Darvill, 2001) consisting of diachronic and interdisciplinary research including geomorphology, palaeogeography, remote sensing, archaeological fieldwork, geophysical surveys, ancient and medieval archaeological, epigraphic and literary sources, toponymy and historical cartography lon the numerous sources indispensable for correct topographic-archaeological research see Quilici \& Quilici Gigli, 2004: 23-61). The projects, which are being carried out in very close collaboration with the relevant Soprintendenze per i Beni Archeologici and the different levels of local government (municipal, provincial, and regional), aim to provide useful data for heritage management and town/territorial planning (e.g. see Francovich, Pellicanò \& Pasquinucci, 2001).

Particular attention is being paid to palaeogeographic aspects. Landscape changes in North coastal Tuscany and the related submarine areas are being studied in collaboration with researchers from the Department of Earth Sciences, University of Pisa (Pasquinucci \& Menchelli, 2012a). Geoarchaeological surveys and drilling campaigns are in progress in the Vada Volaterrana area to reconstruct the ancient lagoon landscapes and their transformations. In the same area, a geophysical survey programme is being conducted to define the extent of the Vada Volaterrana town which was the harbour of Volaterrae from the Etruscan to the Late Roman times (Pasquinucci et al, 2012). 


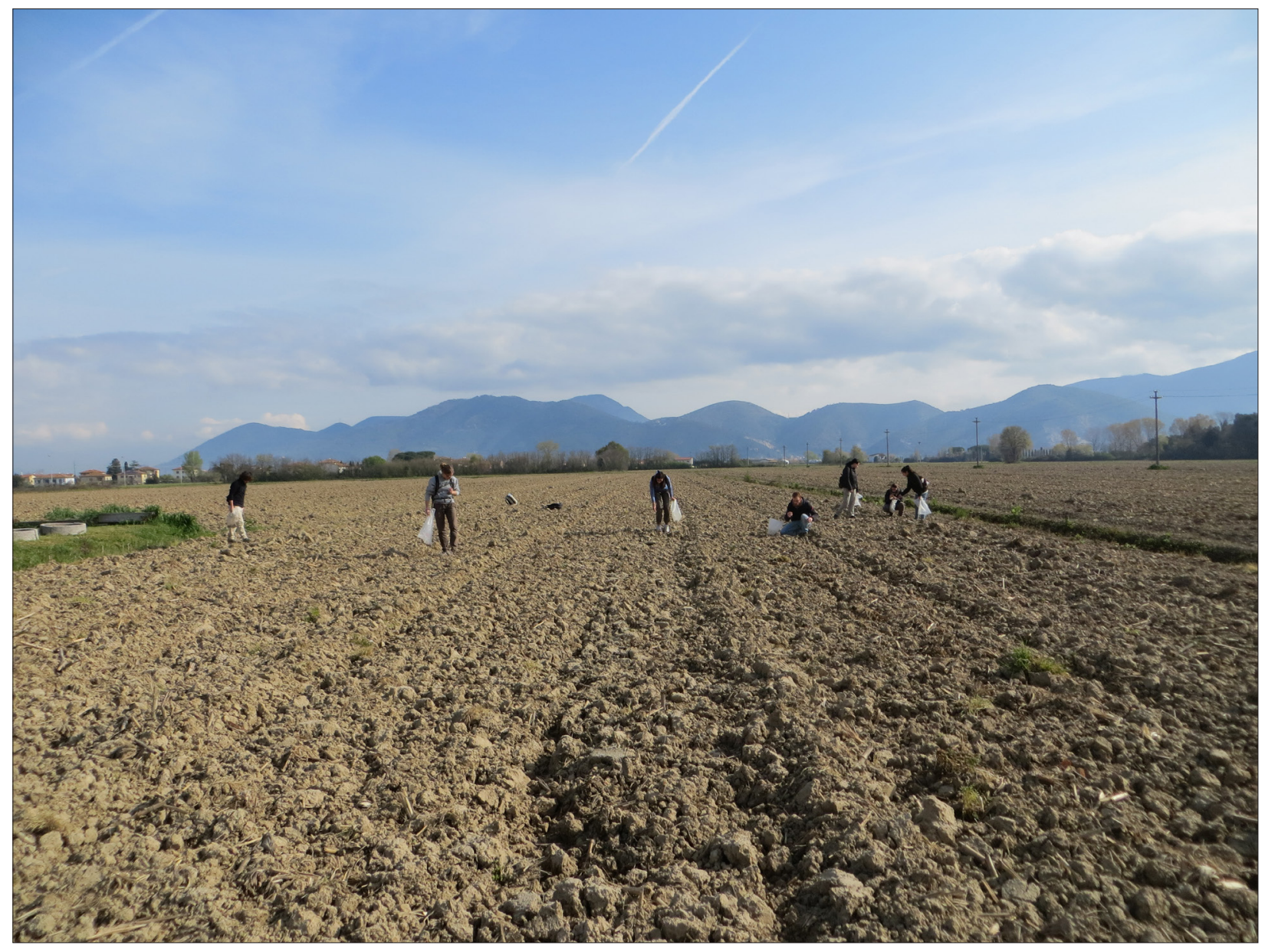

Fig. 1. Comune di San Giuliano (Pisa): survey in progress (photo: author).

In these projects data is organised and managed by GIS platforms (e.g. see lacopini et al, 2012). During the survey, the site and offsite locations are georeferenced and recorded through a mobile system which collects and sends geotagged photos and the site/offsite descriptive data to a Web-GIS platform. This procedure permits an immediate recording of the raw data, providing more time for further research.

As is well known, interdisciplinary research and updated technologies enable the topographer to direct, develop and test his/her fieldwork (see e.g. the important activities of the Consiglio Nazionale delle Ricerche, Istituto per i Beni Archeologici e Monumentali). In general, the ever-increasing development of digital technologies and archaeological theory heighten the debate. Fuzzy theory, Statistical Modelling, Neural Network Analysis, Algorithms, Computer Vision Applications are tools and methods usually discussed and applied to archaeological research le.g. see the papers presented in The Computer Applications and Quantitative Methods in Archaeology Conferences, CAA, and those published in the review Archeologia e Calcolatoril. Obviously, the archaeologists" biggest challenge is anchoring these general applications and models in the realities of human complexity. In any case, the introduction of the new digital technologies to archaeological practices will not provide optimum results unless underpinned by a sound theoretical framework.

In our projects, processual methodology standards are applied in fieldwork and artefact collection and documentation, as well as data management. Nevertheless, we think that geomorphologic, spatial 


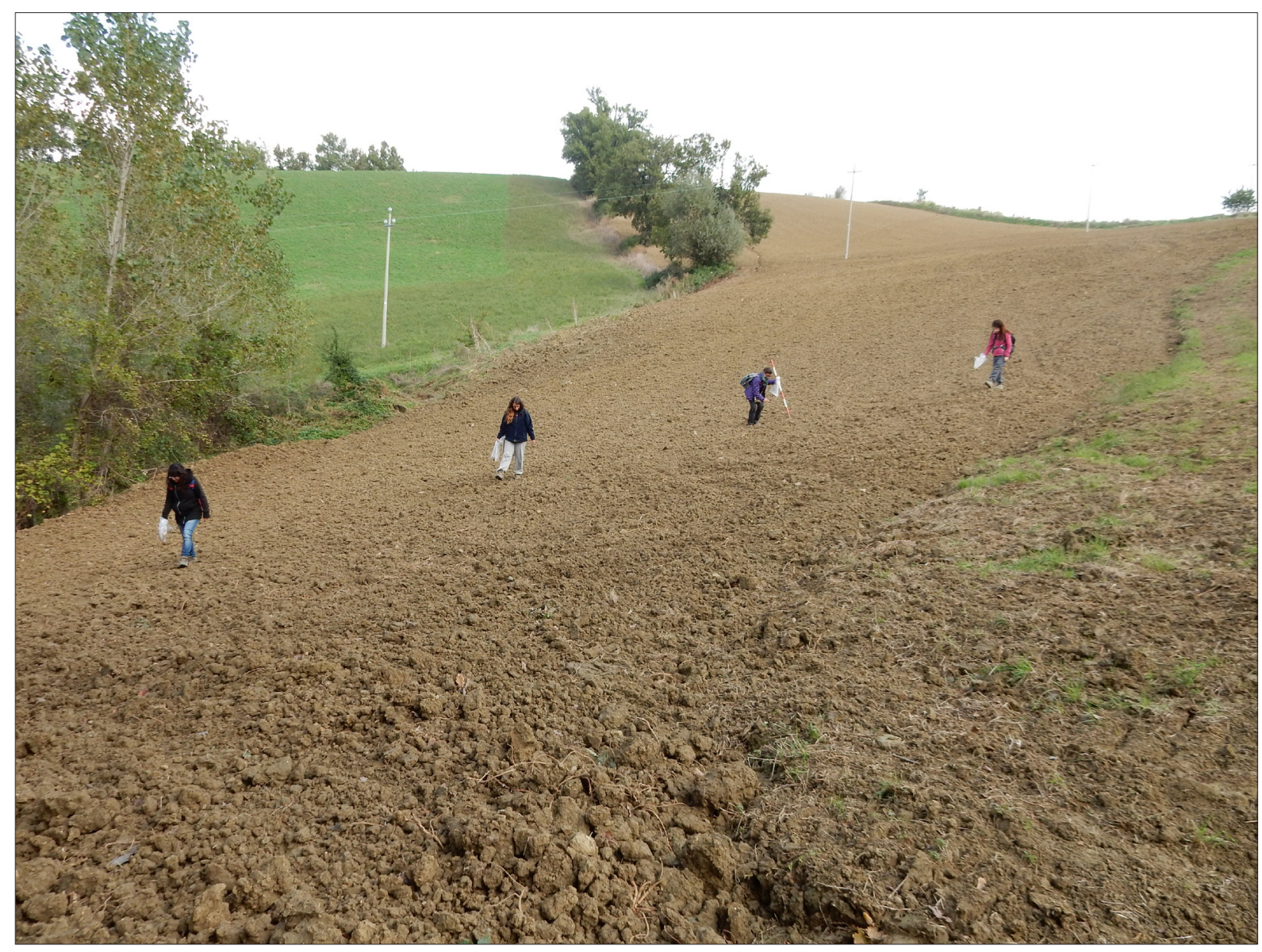

Fig. 2. Comune di Amandola (Fermo): survey in progress (photo: author).

and quantitative evidence should be integrated with qualitative and symbolic data in order to reconstruct all the anthropic activities throughout the centuries (see Pasquinucci \& Menchelli, 2012b). We try to follow a third way, adopting an eclectic and flexible approach, enabling us to avoid the excesses of both processual positivism and of post-processual subjectivism (Bintliff \& Pearce, 2011). Therefore we attempt to outline both landscapes and mindscapes (e.g. see Ashmore \& Knapp, 1999 for conceptualised and ideational landscapes).

For example in South Picenum (Pisa South Picenum Survey Project II), besides spatial analyses aiming at reconstructing the settlements" dynamics in the centuriated landscapes, we also try to reconstruct the stratification of sacred landscapes in the Monti Sibillini area (Montemonaco-Montefortino-Montegallo district). These include the ancestral veneration of the Sybil Roman healthy water cults in caves (the rite of the sanatio) up to the apparition of the Madonna dell'Ambro (Montefortinol to a mute shepherd girl in medieval times. Here the Shrine of Montefortino was built in the sixteenth century; it is still frequented and constitutes an identity component for the local communities, which continue to have collective participation as regards this sacred landscape.

This paper will deal, in particular, with survey methodology: moving to the fieldwork, the crucial point is how to handle the remains on the surface soil which, apart from the fortunate presence of in situ structures, are represented by ploughsoil assemblages consisting of fragmented objects (usually interpreted as sites) or isolated finds loffsites). 
Some remarks will be made about the informative potential of ploughsoil findings, looking for practices to improve their epistemological value and filter bias. I feel consideration should be given to the following points:

1) The formation processes of the ploughsoil assemblages which could imply a variable relationship between the surface evidence and the subsoil remains, due to natural and anthropic agencies (erosion, alluvial deposits, agricultural work, building activities and so on) (fig. 3);

2) Landscape complexity: we should try to envisage the continuum between towns, minor centres, villae, small hamlets and any evidence of anthropic activities. The off-sites, if properly studied and interpreted, can provide equally important information as the sites about the history of the district we are researching Imany case studies examples presented in De Haas, 2012 and Menchelli, 2012).In fact scattered finds in woody mountainous districts can be evidence of mainly seasonal activities (hunting, gathering, breeding, wood and wicker picking) which required ephemeral huts and shelters as well as basic tools and equipment. I find evidence of this in the mountainous district in the Tenna and Aso upper valleys, in the Marches region, where sheep-breeding is still practised in the traditional way and the shepherds working in the area continue to use huts built in perishable materials, as in ancient times. Moreover, peculiar sporadic finds can be related to social and religious practices: a votive statuette found in a spring area can be evidence of a health cult connected with water (sanatio), as documented near the head of the Aso river, in the Montemonaco area (Lucentini, 2001: 79-87) as mentioned above; and

3) Painstaking strategies in collecting and studying pottery which constitutes the main bulk of finds. For example, ceramics should be studied from both quantitative and qualitative points of view. For any site, rigorous calculations of the minimum number of exemplars should be carried out, adding to the "classical" EVE practices (Orton, Tyers \& Vince, 1993) the technical-ar- chaeometric peculiarities of the fragmented vessels: that is potsherds which have the same form can be attributed to different vessels if they show diverse technical peculiarities, e.g. different fabrics.

Moreover, diagnostic elements should be considered as qualitative evidence le.g. tegulae mammatae for identifying the heated part of a villa; third century Latial-Campanian cooking wares as markers of colonial farmsteads or in any case of "Romanised" sites: e.g. see Picchi \& Menchelli, 2011).

On this subject, particular attention should be paid even to "strange" items which we are not able to classify: for example, in the southern ager Pisanus, in the Stagno area a parallelepiped ceramic object (32 cm high) was found in an assemblage formed of impasto sherds dating from the Iron Age. (Panicucci \& Bagnoli, 1986). It was considered significant even if its function and meaning were not identified; a general similarity was found with items documented as supports for salt-making vessels in many contexts, from the Neolithic period until today (Manga Region, Niger) but we did not attempt to interpret it because we were dealing with an isolated find and a comparison which was too vague.

This weak clue was confirmed some years later, when we excavated a Late Bronze Age site specialised in salt-making in the Coltano area, a few kilometres north of Stagno. Here we found more than 10,000 fragmented vessels and eleven parallelepiped and fourteen cylindrical supports similar to the one at Stagno (fig. 4). Therefore it became evident that in the Protohistoric Age this district specialise in salt production: according to palaeogeographic studies, the Coltano and Stagno sites were on the banks of a coastal lagoon and people living there gathered salt by boiling brine in vessels which very often had to be broken in order to recover the crystallised salt. (Pasquinucci \& Menchelli, 2002). The isolated object we found in the Stagno area was only the tip of the iceberg and we were lucky to find something of the underlying part.

As is well known, pottery can provide information for different approaches, both about chrono- 


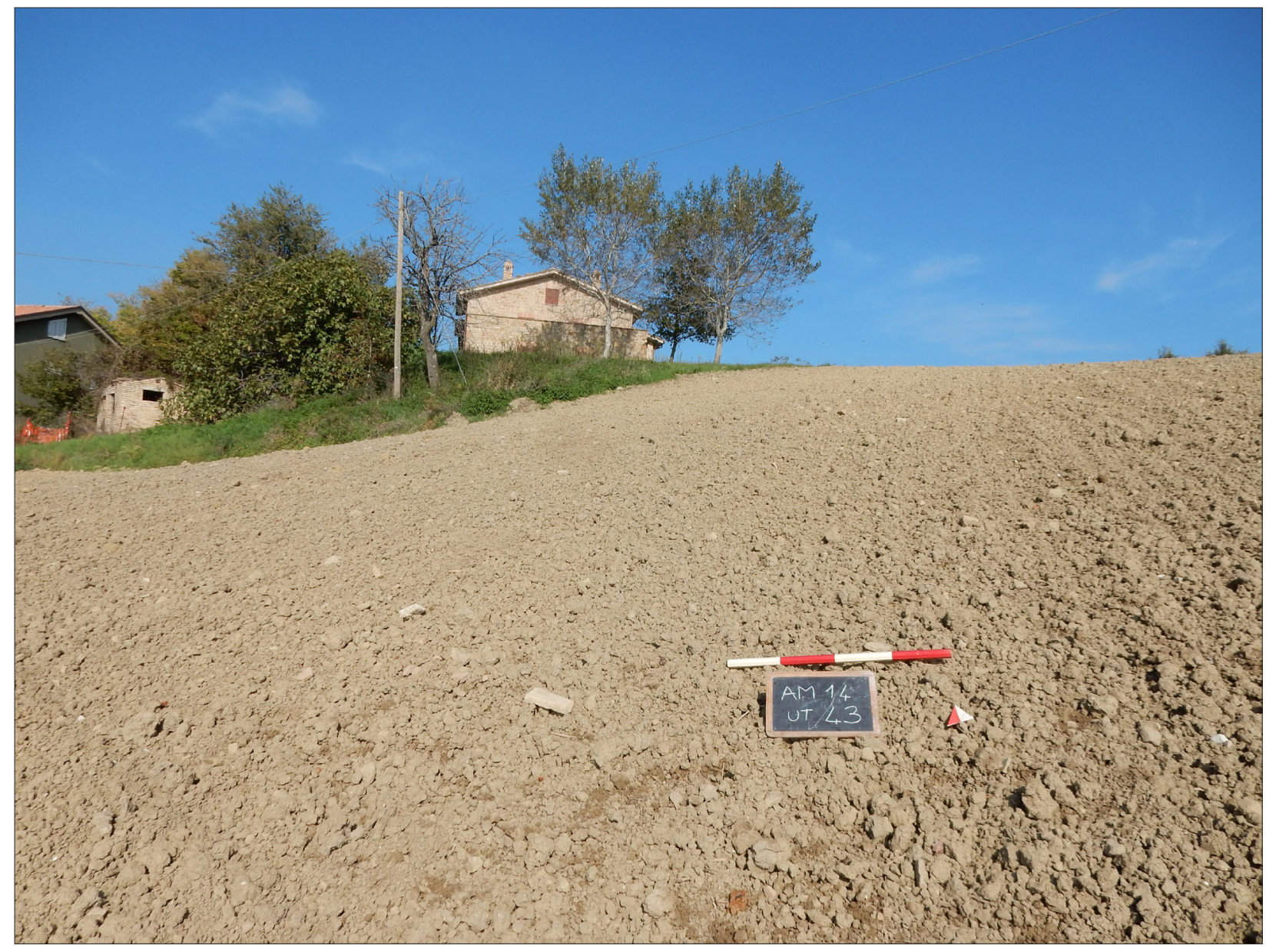

Fig. 3. Comune di Amandola (Fermo): an example of erosion process (photo: author).

typology, technology, function and cognitive, social and economic matters: see the most recent work on this subject by Giannichedda (2014). Therefore, when we find an object we should not use it, reductively, simply in order to date the context, but we should also consider where and how it was produced, its function, the possible role it had in social relations, its significance for economic history, how was it transported from the production site to the place where it was found.

Vessels should not be interpreted from a static point of view, but dynamically, keeping in mind that the objects we found might have had a long life-cycle: therefore we should take into consideration not only the most obvious phases (production-dis-

tribution-consumption-discarding) but also other possibilities: e.g. the treasuring processes and recycling, reuse activities for other functions and purposes (see in general Hahn \& Weiss, 2013).

The latter are evident especially for the amphorae which often appear recycled for trading foodstuffs different from their primary use, as documented by many underwater finds (Abdelhamid, 2013); moreover, amphorae may be present in a surveyed site as reused material for buildings and structures, drainages and enchtrismos tombs. Besides the functional aspects, the possible identity-making role of things and their emotional value should also be considered (Depner, 2013) as the objects we find in the ploughed soil might not have been in use, but derived by processes of decontextualisation, due to treasuring or, on the contrary, having been thrown away or destroyed.

According to all these elements, assemblage 


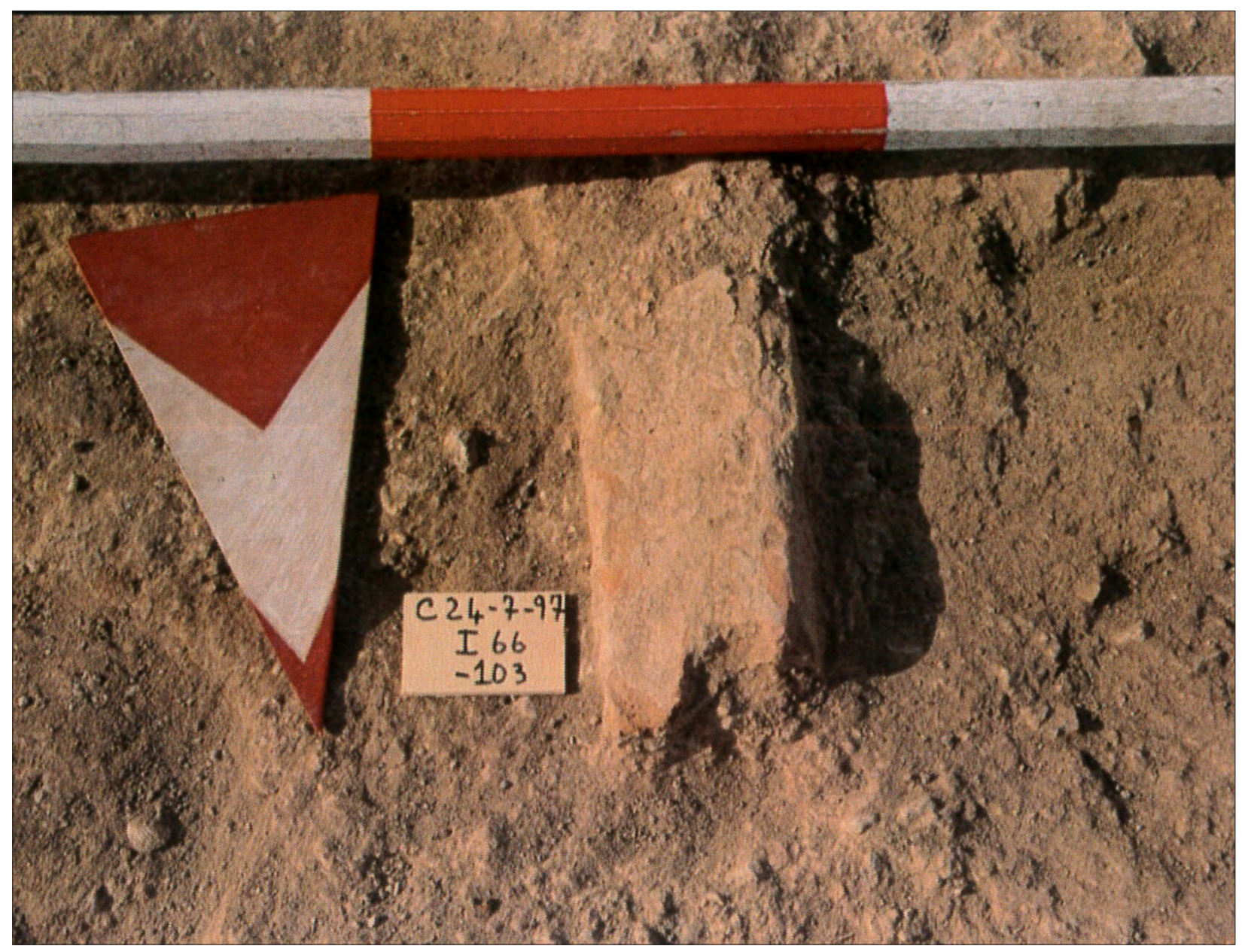

Fig. 4. Coltano (Pisa): a support for salt-making vessels being excavated (photo: author).

ceramics may be considered reliable tools for dating sites if the average chronology of all the finds is compared and, in any case, a flexible gap is taken into consideration.

Ceramics are of fundamental importance for interpreting sites and off-sites and defining their cultural phases, the social and acculturation processes, the economic, technological and commercial trends. In order to exploit fully these potentialities and avoid bias, we have to keep in mind the stochastic characteristics of the processes which have made assemblage and scattered finds available to us (see above, point 1), therefore we have to collect and document what we find as accurately as possible, in all its material and spiritual aspects, but without considering its evidence in absolutist terms for historical reconstruction, because many elements may be missing or undervalued.

For example we know that the ceramic findings constitute the bulk in ploughsoil assemblages because objects made of other material (metal, glass, wood, wicker and so on) might had been lost (For these topic see Menchelli, 2008).

Moreover, differential pottery survival may cause interpretative distortions: Roman ceramic fabrics are the most resistant, while some weaker wares such as the Protohistorical, Etruscan and Piceni impastos are particularly damaged by the attrition processes, most probably because of their temper and firing temperature (Taylor, 2000: 20-21) and this archaeological invisibility causes gaps in the distribution maps. Even Roman thin 


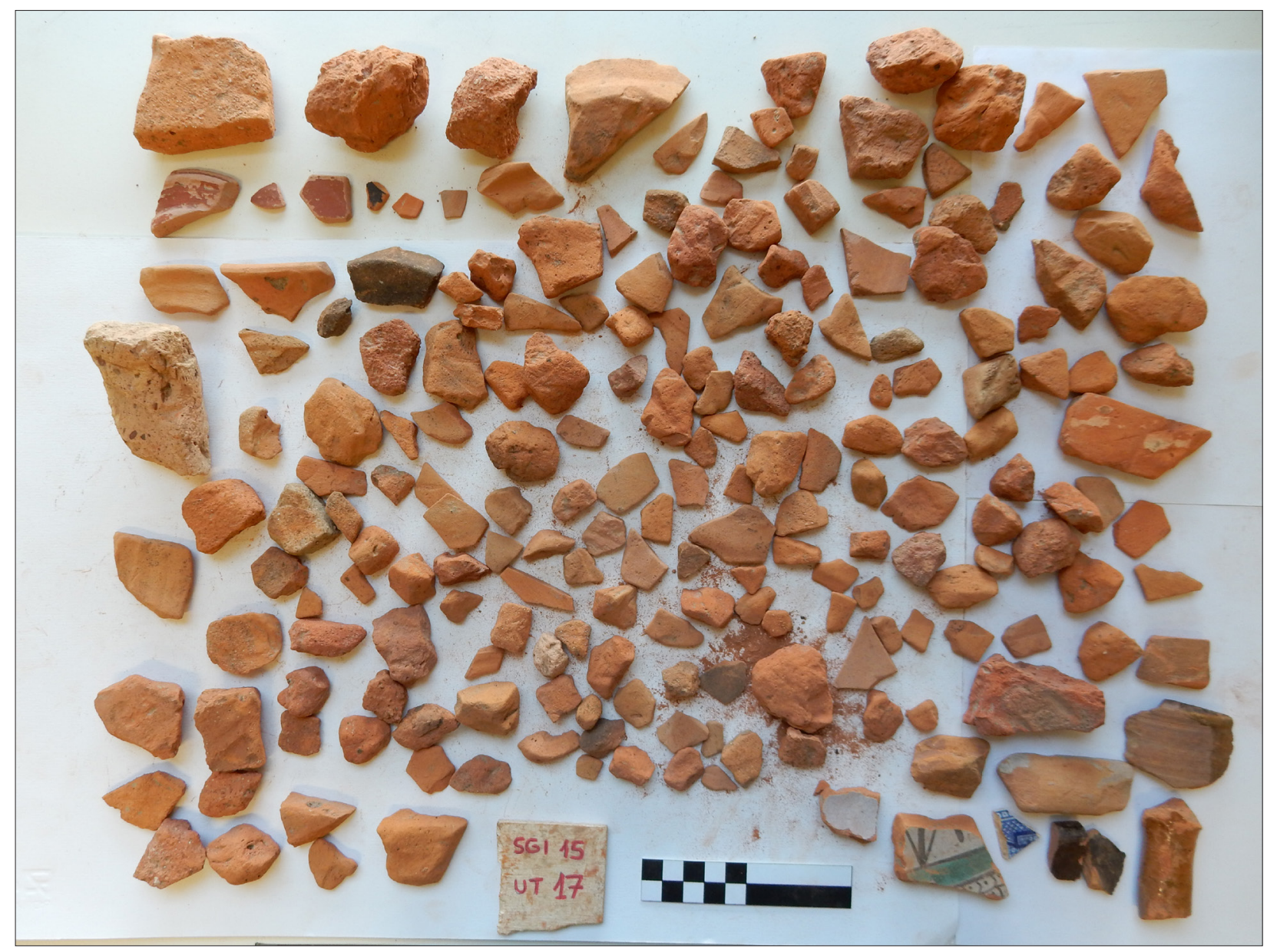

Fig. 5. Comune di San Giuliano (Pisa), Topographic Unit 17: finds considered evidence of a Roman farmstead (photo: M. Parini).

walled pottery may be completely destroyed by the fragmentation processes and due to abrasion, moreover black-glazed and terra sigillata sherds often lose their slip and become unrecognizable,

E. Fentress (2000) said some years ago regarding this topic 'we cannot hope to quantify what is missing, but only record what is there'. I agree to a certain extent, but I think that our task should be more complex: as well as documenting what is there as accurately as possible, we should also keep in mind what is missing, namely utilising all the available sources to try to correct the possible bias which could arise because of the absence of particular categories of materials (Menchelli \&
Picchi, 2014).

For example some ceramic productions lblack grazed pottery, Italian sigillata, African sigillata) had a Mediterranean distribution and therefore had become the "Guide Fossils" for dating all the sites and contexts: this practice is right ladopting the above-mentioned flexible approach) but their absence should not be considered relevant for the chronology of the sites, as a general model of pottery distribution is not applicable to the whole Romanised world.

Accurate studies of local and regional pottery, in particular amphorae, cooking and coarse ware can provide more trustworthy data for the chronotypological approach. Other sources lliterary, documentary, archival, ethnographic, naturalistic, toponymyl of data have to be used to test and integrate the informative potential of the survey results. This interdisciplinary approach is neces- 
sary because the landscape reconstruction derived only from ceramic findings could be biased, as documented by our survey in South Picenum. In the low and middle Tenna and Aso River valleys the settlement patterns are documented by abundant ceramics locally/regionally produced and imported from Mediterranean trade; the villas, farmsteads and minor sites in that area appear to have been active up to the late sixth century, when the Lombards conquered South Picenum (Menchelli, 2012).

On the contrary, in the upper mountain valleys, Late Roman ceramics have not been found and local productions are difficult to date precisely, but other sources enable us to reconstruct a landscape not completely abandoned during the Lombard occupation. For example, toponymy permits the identification of the cultural change which took place in the sixth century AD side by side with the preceding Latin place-names, German ones (such as Gualdo = wood) and churches and sites dedicated to the saints particularly venerated by the Lombards became widespread.

To sum up, following the global approach and its consequent theoretical framework and rigorous methodology, archaeologists will be able to take up the interpretative challenge of defining the landscapes in terms of their different components: sites, off-sites and their historical-functional classification le.g. Roman villas, Late-Etruscan farmsteads and non-datable pens for transhumant sheep). This, after all, is the crucial point in topographic research and the archaeologist's most difficult but creative task: extracting meanings from ploughsoil assemblages (clearly the reference is to Francovich \& Patterson, 2000), trying to follow a third path between the objectivity of the data and interpretative subjectivity, naturally supported by solid survey experience lon these interpretative challenges see Menchelli, 2012: 13-22; Volpe \& Goffredo, 2014: 43).

Obviously, the objective and subjective standards used for these classifications have to be explained clearly, so that the research results of a district can be used for comparisons and large-scale analyses (Alcock \& Cherry, 2004; see Launaro (2011) for an example of comparative research about the Roman Italy). A few fragmented sherds of vessels and bricks and tiles (fig. 5) can be considered evidence of a Roman farmstead on the basis of an archaeologist's acknowledged experience. For example, in the ongoing survey in the ager Pisanus (Comune di San Giuliano) we have decided to test the current archaeological visibility by carrying out surveys in areas already investigated in 1986, where some farmsteads had been identified in the centurial organisation of the /ulia Opsequens Pisana colony (Vaggioli, 1990).

If about 30 years ago, rural Roman sites were characterised by fragments which could be easily classified and where, in any case, of large dimensions, today instead they only present a few fragmented sherds. Obviously the mechanical ploughing system in the last decades has progressively crushed the ancient remains and, moreover, as these sites were published and therefore locally well known, many materials might have been picked up by "Sunday archaeologists". The careful collection and interpretation of these concentrations of small fragments is the last possibility of documenting the Roman settlements, before it is too late las noted by $\mathrm{G}$. Barker many years ago about the changing visibility of the ancient sites: Barker \& Symonds, 1984). Therefore the "legacy data" can be a very important tool in arriving at a truly diachronic perspective to understand the formation processes of the ancient landscapes (regarding this topic see in general Witcher, 2008; for case study examples Cascino, Di Giuseppe \& Patterson, 2012; Kaptijn, Waelkens \& Poblome, 2013).

In conclusion, the above-mentioned accurate and interdisciplinary practices can be useful in reconstructing the ancient landscapes in their complexity, diachronically identifying the paleogeographic changes and the trends of settlement patterns, the town-countryside relationship, infrastructural networks, commercial flows and social, religious and economic activities. A multiscale approach should be adopted, following a local/ global dialectic, which considers the local data in the Mediterranean political, economic and social context. By applying these procedures we can 
compose a mosaic of mutually comparable local narrations forming historical frameworks which will be increasingly broad and detailed in time and space.

\section{References}

Abdelhamid S, 2013: Against the throw-away-mentality: The Reuse of Amphorae in ancient maritime transport, in Hahn HP \& Weiss H (ed.), Mobility, Meaning \& transformations of Things: 91-106. Oxbow Books, Oxford.

Alcock SE \& JF Cherry (ed.) 2004: Side By Side Survey. Comparative Regional Studies in the Mediterranean World, Oxbow Book, Oxford.

Archeologia e Calcolatori, CNR. Dipartimento Scienze Umane e Sociali, Patrimonio Culturale. Istituto di Studi sul Mediterraneo antico. All'Insegna del Giglio, Florence.

Ashmore W \& AB Knapp (ed.) 1999: Archaeologies of Landscape. Contemporary Perspectives, Blackwell, Malden, MA.

Barker G \& J Symonds 1984: The Montarrenti Survey, 1982-83, Archeologia Medievale, 10, 278-89.

Bintliff J (ed.) 2006: A Companion to Archaeology, Blackwell, Malden, MA/Oxford.

Bintliff J \& M Pearce 2011: The Death of Archaeological Theory?, Oxbow Book, Oxford.

Cascino R, H Di Giuseppe \& H Patterson (ed.) 2012: Veii. The Historical Topography of the Ancient City. A restudy of John Ward Perkin's Survey, British School at Rome, London.

Darvill T, 2001: Traditions of landscape archaeology in Britain: issues of time and scale, in Darvill T \& Gojda M (ed.), One Land, Many Landscapes: 33-45. Archaeopress, Oxford.

De Haas T, 2012: Beyond dots on the map: intensive survey data and the interpretation of small sites and off-sites distributions, in Attema P \& Schörner $\mathrm{G}$ (ed.), Comparative issues in the Archeology of the Roman Rural Landscape: 55-79. Journal of Roman Archaeology Supplementary series 88, Porthsmouth, Rhode Island.

Depner A, 2013: Worthless things? On the difference between devaluing and sorting out things, in Hahn HP
\& Weiss $\mathrm{H}$ (ed.), Mobility, Meaning \& transformations of Things: 78-90. Oxbow Books, Oxford.

Fentress E, 2000: What are we counting for?, in Francovich R \& Patterson H (ed.), Extracting Meanings from Ploughsoil Assemblages: 44-59. Oxbow Book, Oxford.

Francovich R, A Pellicanò \& M Pasquinucci (ed.) 2001: La Carta Archeologica fra ricerca e pianificazione territoriale, All'Insegna del Giglio, Florence.

Francovich R \& H Patterson 2000: Extracting Meanings from Ploughsoil Assemblages, Oxbow Book, Oxford.

Giannichedda E, 2014: Chi ha paura dei manufatti? Gli archeologi hanno paura dei manufatti?, Archeologia Medievale, 41, 79-93.

Hahn HP \& H Weiss (ed.) 2013: Mobility, Meaning \& transformations of Things, Oxbow Books, Oxford.

lacopini E, A Del Rio, L Cherubini, S Menchelli \& M Pasquinucci, 2012: Il Sistema Informativo Territoriale dell'ager Volaterranus: metodologia e metadati, Quaderni Laboratorio Universitario Volterrano, 15, 55-64.

Kaptijn E, M Waelkens \& J Poblome 2013: The Sagalassos Survey 2013. Revisiting Sites in the Territory, News of Archaeology from Anatolia's Mediterranean Areas, 12, 200-207.

Launaro A, 2011: Peasants and slaves. The rural population of Roman Italy (200 BC to AD 100), Cambridge University Press, Cambridge.

Lucentini N, 2001: Le grotte in preistoria. Prospettive per la grotta della Sibilla?, in Piscitelli AM \& Carrobbi M (ed.), Sibilla Sciamana della montagna: 79-87. Editrice Miriamica, Montemonaco.

Mannoni T, 1985: Archeologia globale a Genova, Restauro e città, 1(2), 33-47.

Menchelli S, 2008: Surface material, Sites and Landscape in South Picenum (Marche, Italy), in Vanhaverbeke $\mathrm{H}$, J Poblome, F Vermeulen \& M Waelkens (ed.), Dialogue with sites. The definition of Space and Time in the Roman period: 31-43. Brepols, Turnhout.

Menchelli S, 2012: Paesaggi piceni e romani nelle Marche meridionali. L'Ager Firmanus dall'età tardo-repubblicana alla conquista longobarda, Pisa University Press, Pisa.

Menchelli S, 2014: Survey in Toscana e nelle Marche: la metodologia ed alcuni risultati a confronto in Baldelli $G$ \& Lo Schiavo F (ed.), Amore per l'antico. Dal Tirre- 
no all'Adriatico, dalla Preistoria al Medioevo e oltre. Studi di antichità in ricordo di Giuliano de Marinis: 531-41. Scienze e Lettere, Rome.

Menchelli, S \& G Picchi 2014: Distorsioni interpretative e concretezza epistemologica nello studio delle anfore romane: l'esempio dell'ager Firmanus (Marche meridionali, Italia), Fold\&R Fastionline Documents \& Research, 304, 1-26.

Orton C, P Tyers \& A Vince 1993: Pottery in Archaeology, Cambridge University Press, Cambridge.

Panicucci N \& PE Bagnoli, 1986: Materiali dell'Età del Ferro e arcaici dall'ex Padule di Stagno, in Mazzanti R, Grifoni Cremonesi R, Pasquinucci M, \& Pult Quaglia AM (ed.), Terre e paduli. Reperti, documenti, immagini per la storia di Coltano: 98-106. Bandecchi \& Vivaldi, Pontedera.

Pasquinucci M, S Ducci, S Menchelli, A Ribolini, A Bianchi, M Bini \& S Sartini 2012: Ground Penetrating Radar Survey of Urban Sites in North Coastal Etruria: Pisa, Portus Pisanus and Vada Volaterrana, in Vermeulen F, Burges GJ, Keay S \& Corsi C (ed.), Urban Landscape Survey In Italy and the Mediterranean: 149-59. Oxbow Book, Oxford.

Pasquinucci M \& S Menchelli 2002: The Isola di Coltano Bronze Age Village and the Salt Production in North Coastal Tuscany (Italy), in Weller 0 (ed.), Archéologie du Sel, Techniques et Sociétés dans La Pré- et Protohistoire Européenne, actes du Colloque 12.2 du 24. Congrès de UISPP, 4 septembre 2001, Liège et de la Table ronde du Comité des salines de France, 18 mai 1998, Paris: 177-82. Leidorf, Rahden.

Pasquinucci M \& S Menchelli 2012a: Landscape Transformations in North Coastal Etruria, in Kluiving SJ \& Guttmann-Bond EB (ed.), Landscape Archaeology Between Art And Science From A Multi- To An Interdisciplinary Approach: 179-96. Amsterdam University Press, Amsterdam.

Pasquinucci M \& S Menchelli 2012b: Surveying The Complexity: a Global Approach to Italian Landscapes, in Etopoi, Journal For Ancient Studies, 3, Excellence Cluster Topoi-Berlin Http://Journal.Topoi.Org, 100711.

Pasquinucci M \& S Menchelli, (in press): Rural, Urban and Suburban Communities and their Economic Interconnectivity in North Coastal Etruria (second Century BC-second Century AD), in Tol G \& De Haas
T (ed.), Rural Communities in a Globalizing Economy.

Picchi G \& S Menchelli 2011: Vasa Idonea (Col. 12. 4. 4) nell'Ager Firmanus: usi quotidiani ed attività economiche, Studi Classici ed Orientali, 47, 261-302.

Quilici L \& S Quilici Gigli 2004: Introduzione alla Topografia antica, Il Mulino, Bologna.

Vaggioli MA, 1990: Il territorio di San Giuliano in età romana, in Redi F (ed.), San Giuliano Terme. La storia, il territorio, vol. 1: 125-64. Pacini Editore, Pisa.

Taylor J, 2000: Cultural depositional processes and post-depositional problems, in Francovich R \& Patterson $\mathrm{H}$ (ed.), Extracting Meanings from Ploughsoil Assemblages:16-26. Oxbow Books, Oxford.

Volpe G \& R Goffredo 2014: La pietra e il ponte. Alcune considerazioni sull'archeologia globale dei paesaggi, Archeologia Medievale, 41, 39-53.

Witcher RE, 2008: (Re)surveying Mediterranean Rural Landscapes: GIS and Legacy Survey Data, Internet Archaeology, 24. 